\title{
ANALISIS PROTEIN KECAP IKAN BELUT (Monopterus albus) DENGAN VARIASI VOLUME EKSTRAK NANAS (Ananas comosus)
}

\section{PROTEIN ANALYSIS OF EEL (Monopterus albus) WITH PINEAPPLE (Ananas comosus) EXTRACT VOLUME VARIATION}

\author{
Lina Widawati ${ }^{1)}$ \\ ${ }^{1)}$ Prodi Teknologi Pertanian, Fakultas Pertanian, Unived, Bengkulu \\ Email : lina84id@gmail.com
}

\begin{abstract}
ABSTRAK
Ikan belut memiliki kandungan protein tinggi $(18,49 \%)$ sehingga ikan belut dapat diolah menjadi kecap. Tujuan penelitian ini adalah untuk mengetahui kadar protein kecap ikan belut dan kualitas kecap ikan belut melalui uji organoleptik dengan penambahan volume ekstrak nanas. Rancangan penelitian yang digunakan pada penelitian ini adalah Rancangan Acak Lengkap (RAL) dengan variasi volume ekstrak nanas (5\%, 10\%, dan 15\%). Analisis yang dilakukan adalah analisis protein dan analisis organoleptik (uji pembanding). Hasil penelitian didapat bahwa semakin tinggi volume ekstrak nanas maka semakin meningkat kadar protein yang dihasilkan, dimana kadar protein kecap ikan belut paling tinggi adalah pada kecap ikan belut dengan variasi volume ekstrak nanas $15 \%$ sebesar 10,57\%. Berdasarkan parameter warna panelis menilai warna kecap ikan belut dengan variasi volume ekstrak nanas $5 \%$ berbeda dengan kontrol, sedangkan pada kecap ikan belut dengan variasi volume ekstrak nanas $10 \%$ dan $15 \%$ hampir sama dengan kontrol. Berdasarkan parameter rasa panelis menilai rasa kecap ikan belut dengan variasi volume ekstrak nanas $5 \%$ dan $10 \%$ berbeda dengan kontrol, sedangkan kecap ikan belut dengan variasi volume ekstrak nanas $15 \%$ hampir sama dengan kontrol. Berdasarkan parameter aroma panelis menilai kecap ikan belut dengan variasi volume ekstrak nanas $5 \%$ sangat berbeda dengan kontrol, variasi volume ekstrak nanas $10 \%$ berbeda dengan kontrol, dan variasi volume ekstrak nanas $15 \%$ hampir sama dengan kontrol. Berdasarkan parameter tekstur panelis menilai kecap ikan belut dengan variasi volume ekstrak nanas 5\% lebih encer dibanding kontrol, sedangkan tekstur kecap ikan dengan variasi volume ekstrak nanas $10 \%$ dan $15 \%$ sama dengan kontrol.
\end{abstract}

Kata Kunci : ikan belut, kecap ikan, protein, ekstrak nanas

\section{ABSTRACT}

Eel fish has a high protein content (18.49\%) so that eel fish can be processed into fish sauce. The purpose of this study was to determine the protein content of eel fish sauce and the quality of eel fish sauce through organoleptic testing with the addition of the volume of pineapple extract. The research design used in this study was a completely randomized design (CRD) with variations in the volume of pineapple extract $(5 \%, 10 \%$, and $15 \%)$. The analysis carried out was protein analysis and organoleptic analysis (comparative test). The results showed that the higher the volume of pineapple extract, the higher levels of protein produced, where the highest protein content of eel fish sauce was in eel fish sauce with a 
volume variation of $15 \%$ pineapple extract of $10.57 \%$. Based on the panelist color parameters assess the color of eel fish sauce with a volume variation of 5\% pineapple extract different from the control, whereas in eel fish sauce with a variation of the volume of pineapple extract $10 \%$ and $15 \%$ almost the same as the control. Based on the taste parameters the panelists assessed the taste of eel fish sauce with a volume variation of pineapple extract $5 \%$ and $10 \%$ different from the control, whereas eel fish sauce with a variation of $15 \%$ pineapple extract volume was almost the same as the control. Based on the aroma panelist parameters assess eel fish sauce with a volume variation of $5 \%$ pineapple extract is very different from the control, the volume variation of pineapple extract $10 \%$ is different from the control, and the volume variation of $15 \%$ pineapple extract is almost the same as the control. Based on the texture parameters of the panelists, assessing eel fish sauce with a volume variation of 5\% pineapple extract was more watery than the control, while the texture of fish sauce with a variation of the volume of pineapple extract $10 \%$ and $15 \%$ was the same as the control.

Keywords: eel fish, fish sauce, protein, organoleptic, pineapple extract

\section{PENDAHULUAN}

Ikan belut memiliki kandungan protein $(18,49 \%)$, setara dengan protein daging sapi, lebih tinggi dari protein telur $(12,89 \%)$. Seperti jenis ikan lainnya, nilai cerna protein pada belut juga sangat tinggi, sehingga sangat cocok sumber protein bagi semua kelompok usia, dari bayi hingga usia lanjut. Belut juga kaya akan zat besi (20\%), lebih tinggi dibandingkan zat besi pada telur dan daging sapi (2,28\%) (Purnama,2009).

Ikan belut biasanya dikonsumsi oleh masyarakat dalam bentuk segar sebagai lauk pauk. Oleh karena itu, perlu dilakukan diversifikasi produk perikanan seperti pembuatan kecap ikan. Berdasarkan Standar Nasional Indonesia (BSN, 1996), kecap ikan di definisikan sebagai produk cair yang diperoleh dengan hidrolisis ikan atau proses kimia. Kecap ikan mempunyai cita rasa yang berbeda dengan kecap kedelai, warnanya bening kekuningan sampai coklat muda, rasanya relatif asin dan banyak mengandung senyawa-senyawa nitrogen. Kecap yang baik memiliki kandungan protein $6 \%$, lemak $1 \%$, karbohidrat $9 \%$ dan air 63\% (Winarno, 1992).

Secara tradisional, kecap ikan dibuat dengan cara fermentasi menggunakan garam sebaggai senyawa pengontrol mikroba dan memerlukan waktu fermentasi antara 6 hingga 12 bulan (Adawyah, 2008). Waktu proses yang lama merupakan kelemahan, sehingga perlunya alternatif untuk mempercepat proses pengolahan kecap ikan. Salah satu proses yang digunakan adalah menggunakan enzim untuk mempercepat proses fermentasi. Fermentasi ikan yang membutuhkan waktu lama bisa dipercepat dengan menggunakan enzim seperti 
bromelin (Iskandar dan Widyasirini, 2009).

Enzim bromelin adalah enzim yang secara alami terdapat pada buah dan batang nanas. Bromelin merupakan salah satu jenis enzim protease sulfhidril yang mampu menghidrolisis ikatan peptida pada protein atau polipeptida menjadi molekul yang lebih kecil yaitu asam amino (Prasetyo, dkk, 2012). Rekayasa penambahan enzim proteolitik sebelum fermentasi dapat mempersingkat waktu pembuatan kecap ikan. Dalam hal ini tidak diperlukan lagi waktu adaptasi mikroorganisme untuk menghasilkan enzim yang dapat menghidrolisis protein. Selain itu, penggunaan enzim untuk menghidrolisis protein akan menghasilkan kecap yang mempunyai komposisi lebih lengkap dibandingkan hasil hidrolisis secara kimia (Iskandar dkk, 2009).

Kecepatan reaksi enzimatis pada umumnya dipengaruhi oleh konsentrasi substrat, semakin tinggi konsentrasi substrat maka reaksi enzimatis semakin cepat pada sampai suatu saat menjadi konstan (Winarno, 1992). Sehingga perlunya penelitian pengaruh penambahan ekstrak nanas terhadap mutu kecap ikan belut.

\section{METODE PENELITIAN}

Bahan dan Alat
Bahan yang digunakan adalah belut, nanas muda, air, kluwak, phekak, bawang putih, daun salam, daun sereh, gula merah, ketumbar, kunyit, garam, air perasan jeruk, dan bahan untuk analisis protein dan organoleptik. Peralatan yang digunakan antara lain : panci, kompor, blender, magic jar, kain (saringan), saringan teh, pisau, baskom plastic, dan alat untuk analisis protein dan organoleptik.

\section{Prosedur Penelitian}

1. Pembuatan sari nanas

1) Pengupasan

2) Pencucian

3) Pemotongan dan penghancuran

4) Penyaringan

2. Tahapan pembuatan kecap belut

1) Ikan belut segar dimatikan dan disiangi.

2) Perendaman belut dalam larutan jeruk selama 5 menit

3) Perebusan pertama ikan belut kurang lebih 15 menit untuk mempermudah pemisahan daging dan tulang ikan belut.

4) Ikan belut dihaluskan menggunakan blender.

5) Pencampuran daging yang sudah dihaluskan dengan sari nanas $(5 \%$, $10 \%$, dan $15 \%$ ). 
6) Daging belut yang sudah tercampur dengan sari nanas, ditambahkan garam (3\%).

7) Daging belut diinkubasi selama 3 hari pada suhu $75-80^{\circ} \mathrm{C}$.

8) Setelah diinkubasi selama 3 hari air belut dan nanas disaring selanjutnya dipanaskan dan ditambahkan bumbu-bumbu yang telah dihaluskan kecuali daun salam dan sere, gula merah dimasak selama 2 jam.

9) Penyaringan setelah perebusan 2 jam. Kecap disaring kembali sehingga diperoleh kecap sebenarnya tidak tercampur dengan bumbu-bumbu.

10) Kecap dikemas dengan botol yang telah disterilkan.

11) Dilakukan analisis protein dan organoleptik kecap ikan belut.

\section{Rancangan Percobaan dan Analisis}

Rancangan yang digunakan dalam penelitian ini yaitu rancangan acak lengkap (RAL). Untuk mengetahui pengaruh perlakuan terhadap masing masing perlakuan kecap ikan belut dengan sari nanas yang dihasilkan digunakan uji statistik analisis varian (ANOVA).

Analisis yang dilakukan adalah analisis protein dan uji organoleptik. Kadar protein menggunakan Metode
Makro Kjeldahl (Association of Official Analytical Chemist (AOAC), 1990).

Kadar protein $=\frac{\mathrm{V} \times \mathrm{Nx} 0,014 \times 6,25 \times \mathrm{P}}{\text { gram contoh }} \times 100 \%$ keterangan :

$\mathrm{V}=$ Volume titrasi contoh

$\mathrm{N}=$ Normalitas larutan $\mathrm{HCl}$ atau

$\mathrm{H}_{2} \mathrm{SO} 4$ sebagai penitar

$\mathrm{P}=$ Faktor pengencer $100 / 5$.

Analisis organoleptik menggunakan metode uji pembanding. Uji pembanding dilakukan terhadap kecap ikan belut dengan menggunakan 20 orang panelis dengan cara membandingkan kecap ikan belut dengan kecap ikan yang telah beredar dipasaran. Menurut Nopianti (2004) skala untuk uji pembanding parameter yang dinilai adalah : warna, rasa, aroma, dengan skala penilaian sebagai berikut :

1. Sangat berbeda dengan $\mathrm{R}=1$

2. Berbeda dengan $\mathrm{R}=2$

3. Hampir sama dengan $\mathrm{R}=3$

4. Sama dengan $\mathrm{R}=4$

5. Lebih baik daripada $\mathrm{R}=5$

Sedangkan penilaian untuk tekstur dengan skala penilaian sebagai berikut :

1. Lebih encer dari $\mathrm{R}=1$

2. Agak encer dari $\mathrm{R}=2$

3. Sama dengan $\mathrm{R}=3$

4. Lebih kental dari $\mathrm{R}=4$

5. Sangat kental $=5$ 
Keterangan : $\mathrm{R}$ adalah kecap ikan produksi Indofood sebagai kontrol

\section{HASIL DAN PEMBAHASAN}

\section{Kadar Protein Kecap Ikan Belut}

Protein merupakan indikator gizi yang penting dilihat pada suatu produk makanan termasuk kecap ikan. Protein juga merupakan suatu zat yang sangat penting bagi tubuh manusia sebagai zat pembangun dan zat pengatur (Winarno, 1997). Nilai kadar protein kecap ikan belut antara $7,64 \%$ hingga $10,57 \%$. Hasil analisis protein kecap ikan belut dapat dilihat pada tabel 1 .

Dari Tabel 1. dapat dilihat bahwa protein kecap ikan belut tertinggi pada perlakuan variasi volume ekstrak nanas $15 \%$. Persentase rata-rata kadar protein dengan penambahan volume ekstrak nanas yang berbeda menunjukkan bahwa semakin tinggi volume ekstrak nanas maka semakin meningkat kadar protein yang dihasilkan. Menurut Loekman, dkk
(2008) semakin meningkatnya kandungan enzim bromelin pada ekstrak nanas sebagai biokatalisator yang dapat mempercepat reaksi pemecahan protein menjadi asam amino. Selain itu, enzim bromelin mengandung senyawa steroid dan saponin. Kedua senyawa tersebut dapat memecah ikatan peptida protein sehingga nilai kadar protein meningkat. Menurut penelitian Aji (2010) semakin meningkat level enzim bromelin yang ditambahkan dalam pembuatan kecap keong maka kadar protein yang dihasilkan akan meningkat.

\section{Organoleptik Warna Kecap Ikan Belut \\ Warna merupakan sifat yang tampak dan dapat dilihat oleh mata sebagai penentu mutu suatu produk. Pada umumnya untuk menilai suatu produk warna adalah yang pertama bisa kita lihat sebelum kita mencicipinya. Warna yang tampak pada uji organoleptik kecap ikan belut dapat dilihat pada tabel 2 .}

Tabel 1. Hasil Analisis Kadar Protein Kecap Ikan Belut

\begin{tabular}{|c|l|}
\hline Variasi Volume Ekstrak Nanas & Protein (\%) \\
\hline $5 \%$ & $7,64 \mathrm{a}$ \\
\hline $10 \%$ & $9,13 \mathrm{~b}$ \\
\hline $15 \%$ & $10,57 \mathrm{c}$ \\
\hline
\end{tabular}

Keterangan : Angka yang diikuti huruf yang sama menunjukkan tidak berbeda nyata pada taraf $\alpha 5 \%$. 
Tabel 2 Rerata Perbandingan Warna Kecap Ikan Belut

\begin{tabular}{|c|l|}
\hline Variasi volume ekstrak nanas & \multicolumn{1}{|c|}{ Warna } \\
\hline $5 \%$ & $1,68 \mathrm{~b}$ \\
\hline $10 \%$ & $2,95 \mathrm{ab}$ \\
\hline $15 \%$ & $3,4 \mathrm{a}$ \\
\hline
\end{tabular}

Ket : Skala penilaian 1:= Sangat berbeda dengan kontrol ( $\mathrm{R}$ ), 2 = Berbeda dengan Kontrol (R ), 3= hampir sama dengan R, 4= Sama dengan R, 5= Lebih baik daripada R. Dimana R adalah sampel kecap ikan yang telah beredar dipasaran

Warna kecap biasanya berwarna hitam, atau hitam kecoklatan. Pada uji organoleptik kecap ikan belut, kecap yang dihasilkan berwarna coklat terang, coklat kehitaman dan hitam kecoklatan. Warna hitam yang terlihat pada kecap manis karena penggunaan gula, warna pada kecap juga dipengaruhi oleh banyaknya gula dan jenis gula. Menurut Soraya(2008) bahwa proses pemanasan dapat menyebabkan reaksi pencoklatan meliputi flavor dan warna bahan pangan, warna gelap pada kecap disebabkan karamelisasi dan penambahan bumbu. Kecap ikan belut menggunakan bumbu kluwak sebagai pewarna hitam alami, kualitas warna kecap belut juga dipengaruhi oleh bagus atau tidak nya kluwak yang digunakan.

Pada tabel 2 menunjukkan bahwa panelis menilai kecap ikan belut mirip dengan $\mathrm{R}$ pada konsentrasi sari nanas 10 dan $15 \%$. Karena pada konsentrasi $5 \%$ kecap yang dihasilkan berwana coklat, sedangkan pada konsentrasi nanas 10\% berwarna coklat tua dan $15 \%$ kecap yang dihasilkan berwarna hitam layaknya kecap ikan yang telah beredar di pasaran. Pengaruh penambahan nanas juga mempengaruhi warna pada kecap hal ini dikarenakan terbentuknya warna hasil kerja enzim bromelin yang mampu membentuk molekul yang sederhana. Selain itu, jumlah konsentrasi enzim yang digunakan merupakan salah satu penyebab warna gelap kecoklatan akibat terjadinya reaksi browning baik secara oksidatif maupun non-oksidatif antara asam amino dan gula.(Soraya.2008)

\section{Organoleptik Rasa Kecap Ikan Belut}

Hasil analisis rasa kecap ikan belut dapat dilihat pada Tabel 3. Pada Tabel 3 menunjukkan bahwa panelis menilai kecap ikan belut dengan variasi volume ekstrak nanas 5\% dan $10 \%$ tidak berbeda nyata, namun berbeda nyata dengan variasi volume ekstrak nanas $15 \%$. Kecap ikan belut dengan variasi volume ekstrak nanas $5 \%$ dan $10 \%$ berbeda dengan 
kontrol. Sedangkan pada variasi volume ekstrak nanas $15 \%$ hampir sama dengan kontrol. Penilaian rasa pada produk lebih banyak melibatkan indera pengecap melalui lidah kita bisa merasakan rasa manis, asam, asin, gurih dan sebagainya. Rasa sangat penting dalam mempengaruhi derajat penerimaan oleh konsumen (Choirudin, 1990).

Berdasarkan uji organoleptik terhadap rasa kecap ikan belut dengan 3 perlakuan konsentrasi nanas menghasilkan rasa yang paling mirip dengan $\mathrm{R}$ terletak pada konsentrasi nanas $15 \%$ diikuti konsentrasi nanas 10\%. Namun hal pembeda yang diamati panelis dengan kontrol (R) yaitu rasa asin. Kecap ikan memiliki rasa asin dan sangat asin. Hasil menunjukkan bahwa setiap sampel hasilnya sama yaitu asin. Menurut Soraya (2008) menyatakan bahwa campuran bumbu berguna untuk menambah aroma, cita rasa dan tujuan utama pemakaian bumbu atau rempah-rempah pada masakan adalah untuk meningkatkan rasa yang enak dan gurih ,sehingga meningkatkan selera makan. Semakin tinggi jumlah enzim maka semakin tinggi pula substrat yang terhidrolisis maka semakin banyak pula filtrat yang dihasilkan. Menurut (Yudihapsari.2009) bahwa kecap asin diperoleh dari filtrat hasil ekstraksi tampa atau ditambah sedikit gula.

\section{Organoleptik Aroma Kecap Ikan Belut}

Suatu industri pangan menganggap sangat penting untuk melakukan uji aroma, karena dapat diketahui dengan cepat bahwa produk tersebut disukai atau tidak. Hasil analisis aroma kecap ikan belut dapat dilihat pada Tabel 4.

Tabel 3 Rerata Perbandingan Rasa Kecap Ikan Belut

\begin{tabular}{|c|c|}
\hline Variasi volume ekstrak nanas & Rasa \\
\hline $5 \%$ & $2,2 \mathrm{a}$ \\
\hline $10 \%$ & $2,3 \mathrm{a}$ \\
\hline $15 \%$ & $2,65 \mathrm{a}$ \\
\hline
\end{tabular}

Ket : Skala penilaian 1:= Sangat berbeda dengan kontrol ( $\mathrm{R}$ ), $2=$ Berbeda dengan Kontrol ( $\mathrm{R}$ ), 3= Hampir sama dengan R, 4= Sama dengan R, 5= Lebih baik daripada R. Dimana $R$ adalah sampel kecap ikan yang telah beredar dipasaran 


\section{Tabel 4 Rerata Perbandingan Aroma Kecap Ikan Belut}

\begin{tabular}{|c|c|}
\hline Variasi volume ekstrak nanas & Aroma \\
\hline $5 \%$ & $1,4 \mathrm{~b}$ \\
\hline $10 \%$ & $2,4 \mathrm{a}$ \\
\hline $15 \%$ & $3 \mathrm{a}$ \\
\hline
\end{tabular}

Ket : Skala penilaian 1:= Sangat berbeda dengan kontrol ( R ), 2 = Berbeda dengan Kontrol ( R ), 3= Mirip dengan R, 4= Sama dengan R, 5= Lebih baik daripada R. Dimana R adalah sampel kecap ikan yang telah beredar dipasaran

Pada tabel 4. menunjukkan bahwa panelis menilai aroma kecap ikan belut dengan variasi volume ekstrak nanas $5 \%$, $10 \%$ dan $15 \%$ berbeda nyata. Kecap ikan belut dengan variasi volume ekstrak nanas $5 \%$ sangat berbeda dengan kontrol, variasi volume ekstrak nanas $10 \%$ berbeda dengan kontrol, dan . variasi volume ekstrak nanas $15 \%$ hampir sama dengan kontrol.

Aroma merupakan tingkat sedap atau tidaknya bau suatu produk saat kita hirup baunya. Dari tabel rerata aroma menunjukkan aroma mirip dengan kontrol pada konsentrasi nanas $15 \%$. Hal ini dikarenakan enzim bromelin pada nanas dengan konsentrasi $15 \%$ pada nanas bekerja memecah protein pada ikan belut bekerja sempurna.

Selain ekstrak yang digunakan ,bumbu juga berperan dalam pembentukan aroma. Adanya perbedaan aroma pada ketiga sampel tersebut karena perbedaan konsentrasi nanas. Pada ketiga sampel yang berbeda maka berbeda pula konsentrasi enzim. Ketiga sampel kecap ikan belut menunjukkan bahwa semakin banyak sari nanas yang ditambahkan maka hasil proses hidrolisis semakin besar, hal ini disebabkan sari nanas yang mengandung enzim bromelin bersifat hidrolase, yaitu enzim yang bekerja karena adanya air Budiarti (2010). Enzim bromelin akan menghidrolisis jaringan ikat lebih banyak dan menyebabkan struktur daging lebih renggang . Proteolisis miofibrill menghasilkan fragmen protein dengan rantai peptida lebih pendek. semakin banyak sari nanas yang ditambahkan maka konsentrasi enzim yang terkandung didalamnya juga semakin besar. Semakin tinggi enzim bromelin maka semakin tinggi aroma kecap yang dihasilkan hal ini dikarenakanprotein yang terurai menjadi asam amino bebas dan peptide yang kemudian akan diubah menjadi senyawasenyawa pembentuk aroma. Menurut (Istinah..2001) bahwa gula merah juga mempunyai aroma yang khas karena 
mengandung benzil alkohol yang merupakan senyawa yang mudah menguap.

\section{Organoleptik Tekstur Kecap Ikan} Belut

Tekstur adalah kualitas tertentu suatu permukaan yang timbul sebagai akibat dari stuktur 3 dimensi dan juga merupakan unsur rupa yang menunjukkan rasa permukaan bahan. Yang sengaja dibuat dan dihadirkan dalam susunan untuk mencapai bentuk rupa sebagai usaha untuk memberikan rasa tertentu pada permukaan bidang suatu bahan atau suatu bahan pangan.. Hasil analisis aroma kecap ikan belut dapat dilihat pada tabel 5.

Pada tabel 5 menunjukkan bahwa panelis menilai kecap ikan belut dengan variasi volume ekstrak nanas $10 \%$ dan $15 \%$ tidak berbeda nyata, namun berbeda nyata dengan variasi volume ekstrak nanas 5\%. Tekstur kecap ikan belut dengan variasi volume ekstrak nanas 5\% lebih encer dibanding kontrol, sedangkan tekstur kecap ikan dengan variasi volume ekstrak nanas $10 \%$ dan $15 \%$ sama dengan kontrol.

Perbedaan ketiga tekstur kecap ikan tersebut disebabkan karena penggunaan volume ekstrak yang bervariasi, selain itu bisa juga dipengaruhi oleh waktu pemasakan dan suhu pemasakan. Menurut Arsyani(2008) menyatakan bahwa perbedaan kekentalan disebabkan karena penggunaan jumlah ekstrak yang bervariasi serta lama dan suhu pemasakan yang sama.

Menurut Hamidi (2008) semakin banyak penambahan ekstrak nanas akan mempengaruhi viskositas hidrolisat yang dihasilkan menjadi semakin baik. Tingkat kekentalan kecap juga dipengaruhi adanya penambahan gula. Adanya penambahan gula menyebabkan terjadinya reaksi maillard antara gula turunan protein yang dihasilkan selama proses pemasakan akibat terjadinya hidrolisis protein oleh panas. Sehingga meningkatkan ketersediaan gugus amino bebas yang mampu bereaksi, selain akibat meningkatnya jumlah gugus karbonil bebas yang tersedia dengan adanya penambahan gula dalam kecap ikan belut. Makin tingginya kadar komponen yang memiliki banyak sisi aktif yang bersifat polar (gula, reduksi, dan sukrosa) menyebabkan larutan tersebut mempunyai sifat hidrofil yang banyak berpengaruh terhadap peningkatan derajat viskositas. 
Tabel 5 Rerata Perbandingan Tekstur Kecap Ikan Belut

\begin{tabular}{|c|c|}
\hline Variasi volume ekstrak nanas & Tekstur \\
\hline $5 \%$ & $2,15 \mathrm{a}$ \\
\hline $10 \%$ & $2,65 \mathrm{a}$ \\
\hline $15 \%$ & $2,85 \mathrm{a}$ \\
\hline
\end{tabular}

Ket : 1= lebih encer dari R, 2= agak encer dari R, 3= sama dengan R, 4= lebih kental dari $\mathrm{R}$, $5=$ sangat kental. $\mathrm{R}$ adalah sampel kecap ikan yang beredar dipasaran

\section{Kesimpulan}

Semakin tinggi volume ekstrak nanas maka semakin meningkat kadar protein yang dihasilkan, dimana kadar protein kecap ikan belut paling tinggi adalah pada kecap ikan belut dengan variasi volume ekstrak nanas 15\% sebesar $10,57 \%$.

Berdasarkan parameter warna panelis menilai warna kecap ikan belut dengan variasi volume ekstrak nanas 5\% berbeda dengan kontrol, sedangkan pada kecap ikan belut dengan variasi volume ekstrak nanas 10\% dan 15\% hampir sama dengan kontrol.

Berdasarkan parameter rasa panelis menilai rasa kecap ikan belut dengan variasi volume ekstrak nanas 5\% dan $10 \%$ berbeda dengan kontrol, sedangkan kecap ikan belut dengan variasi volume ekstrak nanas $15 \%$ hampir sama dengan kontrol

Berdasarkan parameter aroma panelis menilai kecap ikan belut dengan variasi volume ekstrak nanas 5\% sangat berbeda dengan kontrol, variasi volume ekstrak nanas $10 \%$ berbeda dengan kontrol, dan variasi volume ekstrak nanas $15 \%$ hampir sama dengan kontrol.

Berdasarkan parameter tekstur panelis menilai kecap ikan belut dengan variasi volume ekstrak nanas 5\% lebih encer dibanding kontrol, sedangkan tekstur kecap ikan dengan variasi volume ekstrak nanas 10\% dan 15\% sama dengan kontrol.

\section{DAFTAR PUSTAKA}

Adawyah R. 2008. Pengolahan dan Pengawetan Ikan. Jakarta (ID): Bumi aksara.

Arsyani. 2004. Pengaruh Lama Perendaman dan Level Penambahan Nanas terhadap Kualitas Dendeng. Fakultas Peternakan Universitas Hassanudin. Makasar

Budiarti .2010. Pembuatan Kecap Kepala Broiler . Jurnal Skripsi Peternakan dan Perikanan :23-25

[BSN] Badan Standarisasi Nasional. 1996. Kecap Ikan: SNI. 014271-1996. Jakarta (ID): Badan Standardisasi Nasional.

Choirudin. Rudy,1990 Cipta Aroma Rasa. Gramedia Pustaka Utama. Jakarta

Iskandar T, Widyasirini TA. 2009. Pengaruh Enzim Bromelin dan 
Waktu Inkubasi pada Proses Hidrolisis Ikan Lemuru (Sardinella sp.) menjadi Kecap Ikan. Jurnal Buana Sains. 9(2): 183-189

Istinah .2011. Manfaat Gula Merah. Jurnal Pembuatan Kecap Kepala Broiler. 26-28

Loekman S, Karnila R, Dewi K. 2008. Pengaruh Penambahan Konsentrasi Crude Enzim Bromelin Berbeda terhadap Kualitas Kecap Ikan Lele Dumbo (Clarias garepinus). Universitas Riau. Riau

Prasetyo NM, Sari M, Budiyati CN. 2012. Pembuatan Kecap Ikan Gabus secara Hidrolisis
Enzimatis menggunakan Sari Nanas. Jurnal Teknologi Kimia dan Industri. 1(1): 329-337

Soraya ,M.R.2008. Kajian Suhu dan Ph Hidrolisis Enzimatik dengan Papain Amobil terhadap Kualitas Kecap. Program Studi Teknologi Hasil Ternak .Fakultas Peternakan Universitas Brawijaya. Malang

Yudihapsari,E. 2009. Kajian Kadar Protein, $\mathrm{pH}$, Viskositas, Randemen kecap Whey dari Berbagai Tingkat Penggunaan Tepung Kedelai. Program Studi Teknologi Hasil Ternak Fakultas Peternakan Universitas 